\title{
Long-term Blue Light Effects on the Histology of Lettuce and Soybean Leaves and Stems
}

\author{
Tracy A.O. Dougher ${ }^{1}$ \\ Department of Plant Sciences and Plant Pathology, Montana State University, Bozeman, MT 59717 \\ Bruce Bugbee \\ Department of Plants, Soils, and Biometeorology; Utah State University, Logan, UT 84322
}

\begin{abstract}
AdDITIONAL INDEX WORDS. cell division, cell expansion, Glycine max, Lactuca sativa
Abstract. Blue light (320 to $496 \mathrm{~nm}$ ) alters hypocotyl and stem elongation and leaf expansion in short-term, cell-level experiments, but histological effects of blue light in long-term studies of whole plants have not been described. We measured cell size and number in stems of soybean (Glycine max L.) and leaves of soybean and lettuce (Lactuca sativa L.), at two blue light fractions. Short-term studies have shown that cell expansion in stems is rapidly inhibited when etiolated tissue is exposed to blue light. However, under long-term light exposure, an increase in the blue light fraction from $<0.1 \%$ to $26 \%$ decreased internode length, specifically by inhibiting soybean cell division in stems. In contrast, an increase in blue light fraction from $6 \%$ to $26 \%$ reduced soybean leaf area by decreasing cell expansion. Surprisingly, lettuce leaf area increased with increasing blue light fraction $(0 \%$ to $6 \%)$, which was attributed to a 3.1-fold increase in cell expansion and a 1.6-fold increase in cell division.
\end{abstract}

Gross morphological differences induced by low blue light have been observed in several species (Brown et al., 1995; Dougher and Bugbee, 2001; Goins et al., 1997; Hoenecke et al., 1992). In addition to blue light-induced morphological changes, blue light can alter plant biochemical pathways. Guerra et al. (1985) found that in wheat, low-pressure sodium lamps, which do not emit any blue light, decreased activity of enzymes responsible for lignification compared to lamps with blue light fractions $>6 \%$. Low enzyme activity may allow continued cell expansion, which would explain the elongated stems that are typically observed under low blue light. However, to understand the primary biochemical processes that are altered by blue light fraction, we first wanted to understand which basic process, cell expansion or cell division, was affected. While there have been many extensive short-term, cell-level studies of morphological changes with light quality, the histology associated with whole-plant morphological changes has not been characterized.

Blue light-mediated inhibition of stem elongation is often assumed to be caused by a decrease in cell expansion. However, three key studies examining this effect measured only hypocotyl elongation and cell-wall properties, and did not measure cell size (Cosgrove, 1981; Kigel and Cosgrove, 1991; Shinkle and Jones, 1988). Blue light effects may not be consistent across species. In bean (Phaseolus vulgaris L.) leaves, blue light increased cell expansion (Van Volkenburgh et al., 1990). However, all four of these studies were short-term hypocotyl or leaf disc experiments.

In a longer-term study, Rahim and Fordham (1991) found that reducing light intensity (shading) decreased garlic leaf area primarily by a decrease in cell expansion. By contrast, because leaf

Received for publication $22 \mathrm{Aug}$. 2003. Accepted for publication $6 \mathrm{Jan}$. 2004. This research was supported by the National Aeronautics and Space Administration Advanced Life Support Program administered by the Johnson Space Center and the Utah Agricultural Experiment Station, Utah State Univ., Logan. Approved as journal paper no. 7357. Mention of a trademark, proprietary product, or vendor does not constitute a guarantee or warranty of the product by Utah State University and does not imply its approval to the exclusion of other products or vendors that also may be suitable.

1To whom reprint requests should be addressed; e-mail tracyaod@montana.edu expansion is associated more with increasing cell number than cell size (Dale and Milthorpe, 1983), one would predict that long-term leaf area responses to blue light would be primarily mediated by altered cell division.

Dougher and Bugbee (2001) defined long-term blue light dose response curves for soybean and lettuce leaf area and stem length: soybean leaf area decreasing as blue light fraction increased from $6 \%$ to $26 \%$, soybean stem length decreasing as blue light fraction increased from $<0.1 \%$ to $26 \%$, and lettuce leaf area increasing as blue light fraction increased from $<0.1 \%$ to $6 \%$. Using the same methodology, we compared cell size and cell number under known blue light responses. Based on the assumption that the epidermis limits stem and leaf expansion (Dale, 1988; Kutschera, 1992), we measured epidermal cell size and number to account for differences in stem length of soybean (Glycine max L.) and leaf area of soybean and lettuce (Lactuca sativa L.) at two blue light fractions.

\section{Material and Methods}

Cultural conditions. Soybeans (Glycine max cv. Hoyt) and lettuce (Lactuca sativa cv. Grand Rapids) were grown at a photosynthetic photon flux of $500 \mu \mathrm{mol} \cdot \mathrm{m}^{-2} \cdot \mathrm{s}^{-1}, 1000 \mu \mathrm{mol} \mathrm{CO} / \mathrm{mol}$, 16-h photoperiod, $25 / 22{ }^{\circ} \mathrm{C}$ day/night temperature, and $70 \%$ relative humidity. Blue light treatments were selected from a separate experiment demonstrating blue light responses under blue-filtered (yellow cellulose triacetate, Roscolux \#312; Oasis Stage Werks, Salt Lake City, Utah) and unfiltered high-pressure sodium (HPS) and metal halide (MH) lamps (Dougher and Bugbee, 2001). Blue light was defined as wavelengths between 320 to $496 \mathrm{~nm}$ (Table 1). Although red : far-red ratio (600 to $700 \mathrm{~nm}: 700$ to $800 \mathrm{~nm}$ ) varied between lamp types, the ratio was greater than sunlight where the response flattens out and differences in phytochrome photoequilibrium (Sager and McFarlane, 1997) were relatively small (0.82 to 0.86). Dougher and Bugbee (2001) demonstrated that although two lamp types were used to achieve the blue light treatments for soybean, the leaf area and stem length responses were attributed to the change in blue light fraction and not the overall spectral composition of the two lamp types. The blue light treatments for this study were chosen between two blue light fractions where the largest change in leaf 

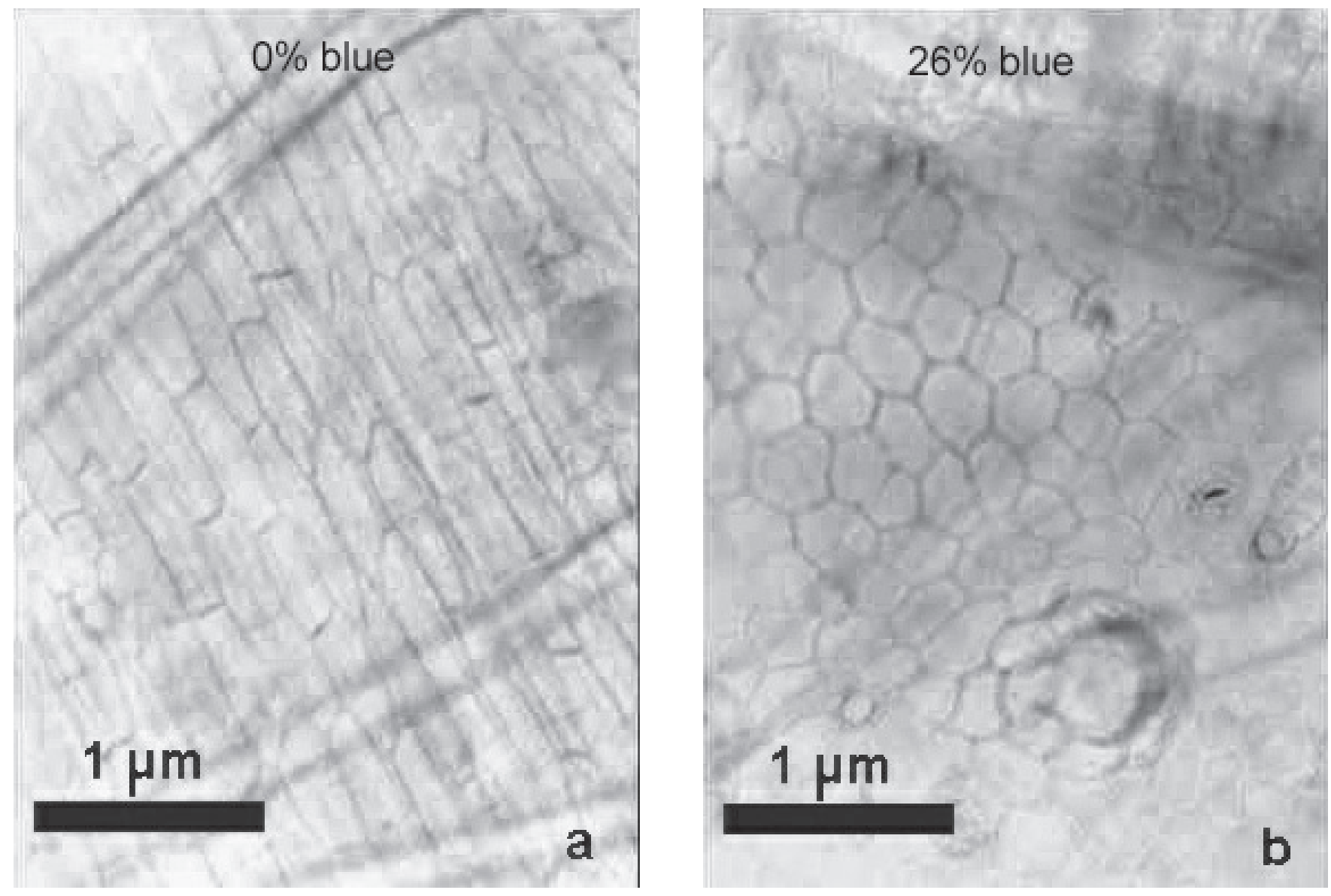

Fig. 1. Microscope photographs of soybean stem epidermal cells from plants grown under a blue light fraction of $<0.1 \%$ (a) or $26 \%$ blue (b). Blue light fraction is the percentage of blue light (320 to $496 \mathrm{~nm})$ to total $(320$ to $700 \mathrm{~nm})$.

area or stem length occurred. Blue light treatments on a photon basis were as follows: soybean stem sections $<0.1 \%$ (HPS plus filter) and $26 \%(\mathrm{MH})$; soybean leaf impressions $6 \%(\mathrm{HPS})$ and $26 \%(\mathrm{MH})$; and lettuce leaf impressions $<0.1 \%$ (HPS plus filter) and $6 \%$ (HPS) (Table 1).Additional details of cultural procedures and environmental conditions are described in Dougher and Bugbee (2001). Leaf and internode samples were taken when expansion was complete. The completion of expansion was determined by measuring internode length and leaf length and width every day until three consecutive days in which measurements were the same.

STEMSECTIONS. Eighteen days after transplanting, soybean stems from each blue light treatment were sectioned in the internode just above the cotyledonary leaves. Internode length was measured, then fresh sections were cut on glass slides in water and the epidermis was peeled away from the sections. Samples were covered with a cover slip and immediately viewed at $25 \times$ and photographed.

LEAF IMPRESSIONS. The middle leaflet of the first trifoliate soybean leaf and the second true leaf of lettuce were sampled in the middle of the leaf(let) 18 and $17 \mathrm{~d}$ after transplanting, respectively. A 4\% $(\mathrm{w}: \mathrm{v})$ solution of Formvar resin in chloroform (polyvinyl-formaldehyde) was painted in a thin layer on each leaf. The solution was allowed to dry for at least $30 \mathrm{~s}$. Samples were then covered with cellophane tape, peeled off the leaf, and mounted on a glass microscope slide. The sampled leaf was then measured with a leaf area meter(LI-COR, Lincoln, Neb.). Leaf impressions were viewed and photographed at $40 \times$. All sampling, viewing, and photographing took place within $2 \mathrm{~h}$.
MicrosCopiC EXAMINATION AND MEASUREMENT. Both stem sections and leaf impressions were viewed under a microscope (Leitz, Laborlux 12 Pol, Wetzal, Germany) and photographed using an attached microcamera (WILD, Heerbrugg, Switzerland). A stage micrometer was used to calibrate the analysis software (ArcView, ESRI, Redlands, Calif.). The analysis software determined cell areas from tracings of the cells. Stem cell number was determined by dividing the internode length by the average longitudinal cell length. Leaf cell number was determined by dividing leaf area by the average cell area.

STATistics. Six plants were sampled under each blue light fraction and blue light fractions were repeated in another location. Blue light comparisons of measured parameters were made using a $t$ test in SAS (SAS Institute, Cary, N.C.).

\section{Results and Discussion}

Soybean stem epidermal cells were visually more elongated and narrow at $0 \%$ blue light than $26 \%$ blue (Fig. 1). Compared with plants grown under $26 \%$ blue light, plants exposed to virtually no blue light had a 4.7-fold increase in soybean stem length (Fig. 2a), which was associated with a 4.5-fold increase in cell number (Fig. 2c). This suggests that blue light inhibited cell division, causing a reduction in soybean stem length. While evidence of blue light suppression of cell expansion exists for etiolated seedlings transferred to blue light (Cosgrove, 1981; Kigel and Cosgrove, 1991), there was no significant difference in cell expansion for soybean exposed 

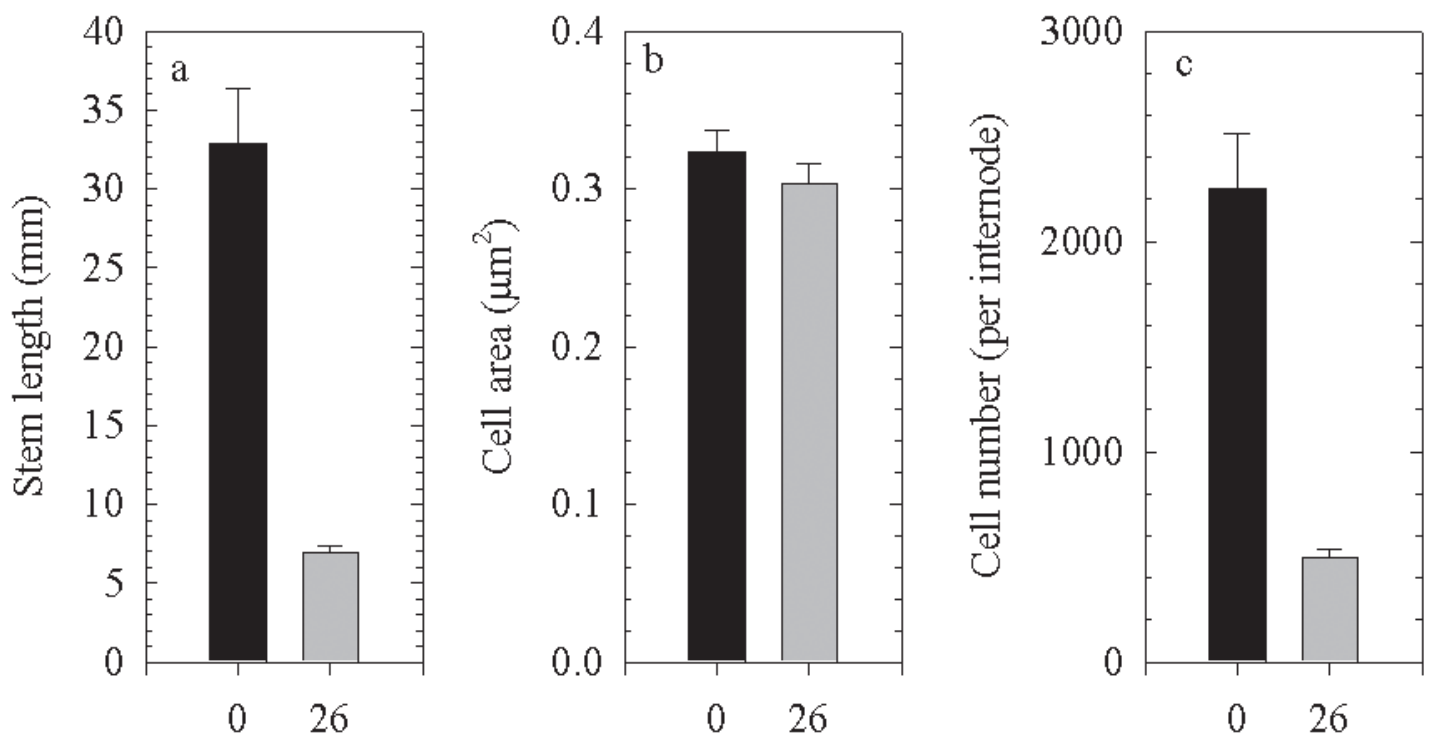

\section{Blue Light Fraction (\%)}

Fig. 2. Effect of $<0.1 \%$ and $26 \%$ blue light fraction on soybean (a) stem length, (b) stem epidermal cell area, and (c) stem epidermal cell number per internode. Error bars represent the standard error of the means. Blue light fraction is the percentage of blue light (320 to $496 \mathrm{~nm})$ to total (320 to $700 \mathrm{~nm}$ ).
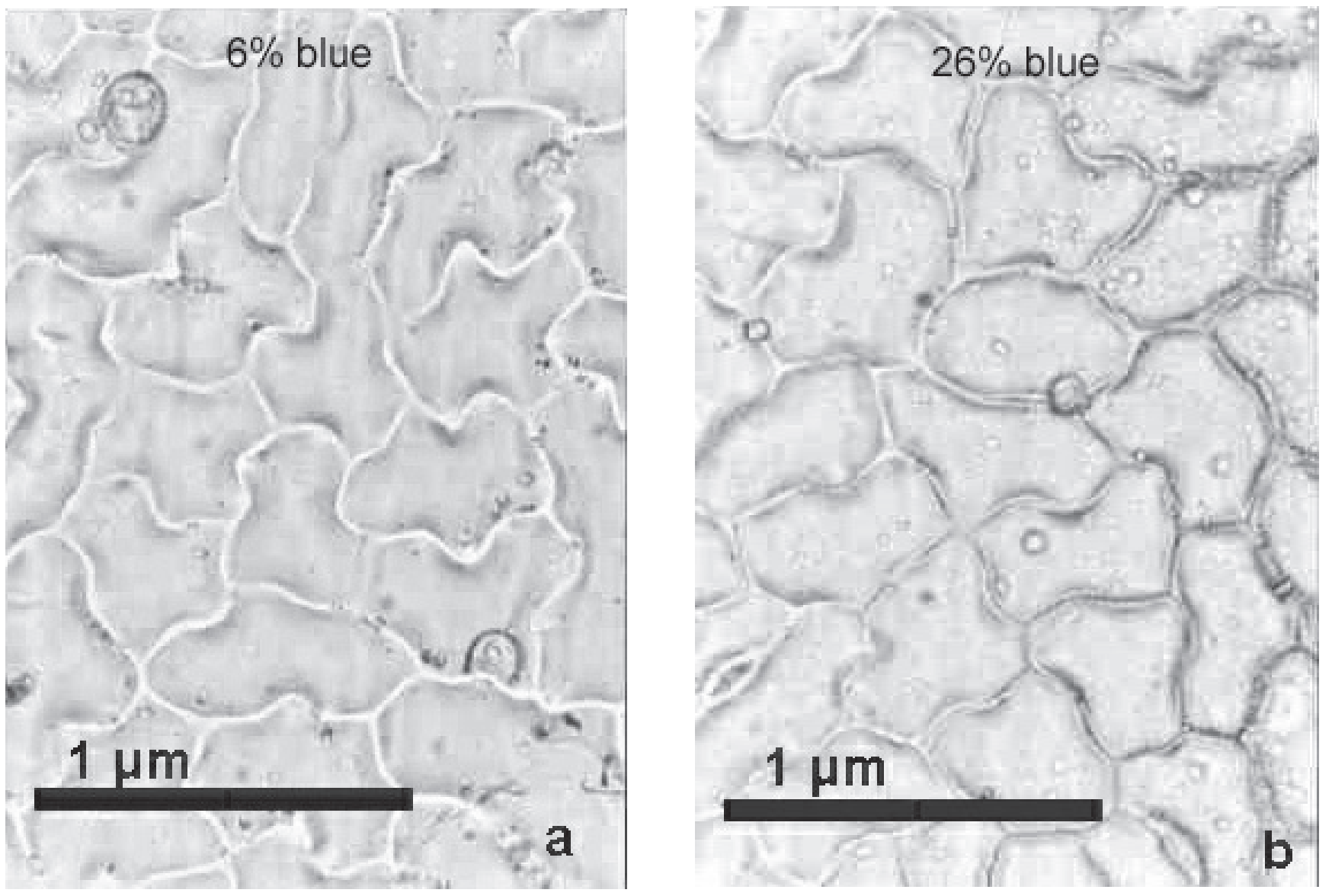

Fig. 3. Microscope photographs of soybean leaf epidermal cells from plants grown under a blue light fraction of $6 \%$ (a) or $26 \%$ blue (b). Blue light fraction is the percentage of blue light (320 to $496 \mathrm{~nm})$ to total (320 to $700 \mathrm{~nm})$. 

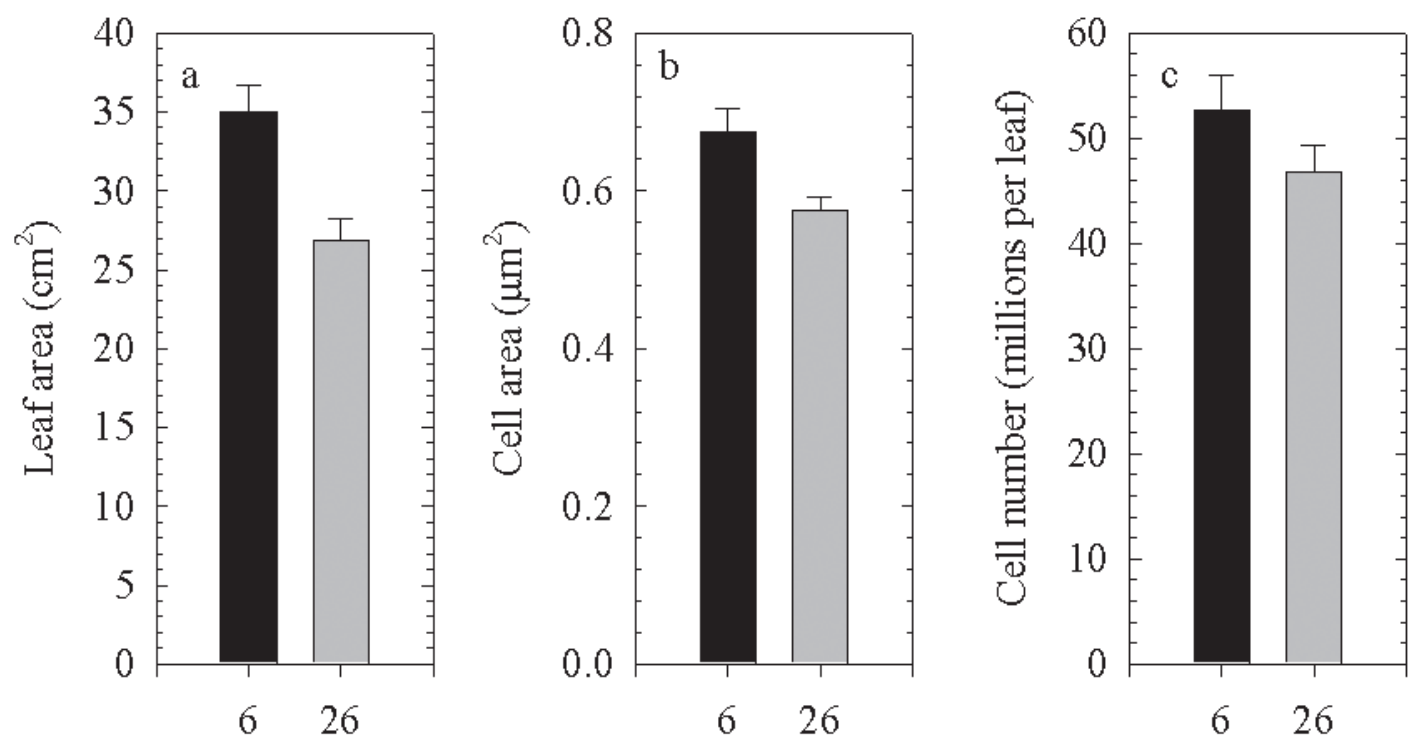

Blue Light Fraction (\%)

Fig. 4. Effect of $6 \%$ and $26 \%$ blue light on soybean (a) leaf area, (b) leaf epidermal cell area, and (c) leaf epidermal cell number. Error bars represent the standard error of the means. Blue light fraction is the percentage of blue light (320 to $496 \mathrm{~nm})$ to total (320 to $700 \mathrm{~nm}$ ).
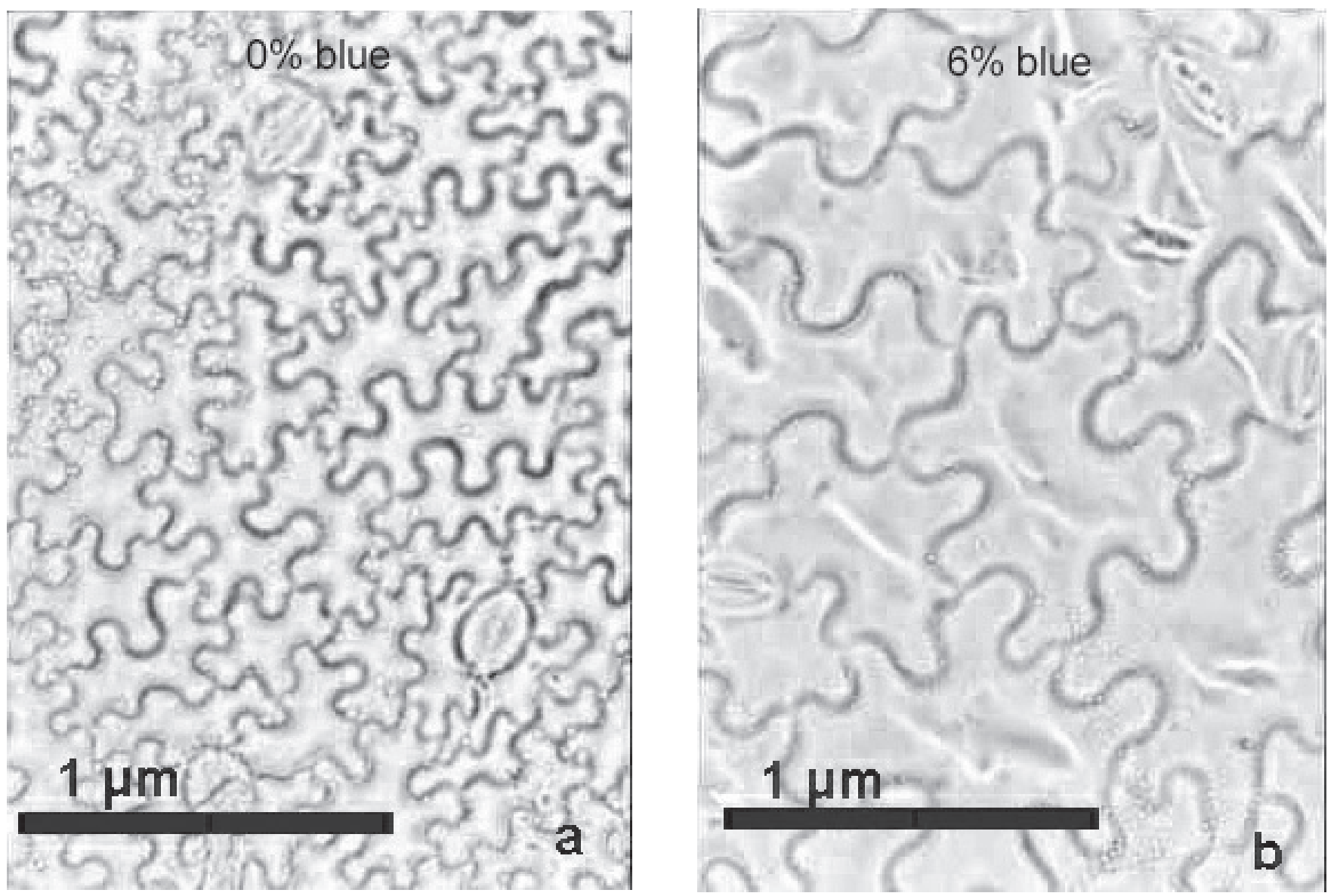

Fig. 5. Microscope photographs of lettuce leaf epidermal cells plants grown under a blue light fraction of $<0.1 \%$ (a) or $6 \%$ blue (b). Blue light fraction is the percentage of blue light (320 to $496 \mathrm{~nm})$ to total $(320$ to $700 \mathrm{~nm})$. 

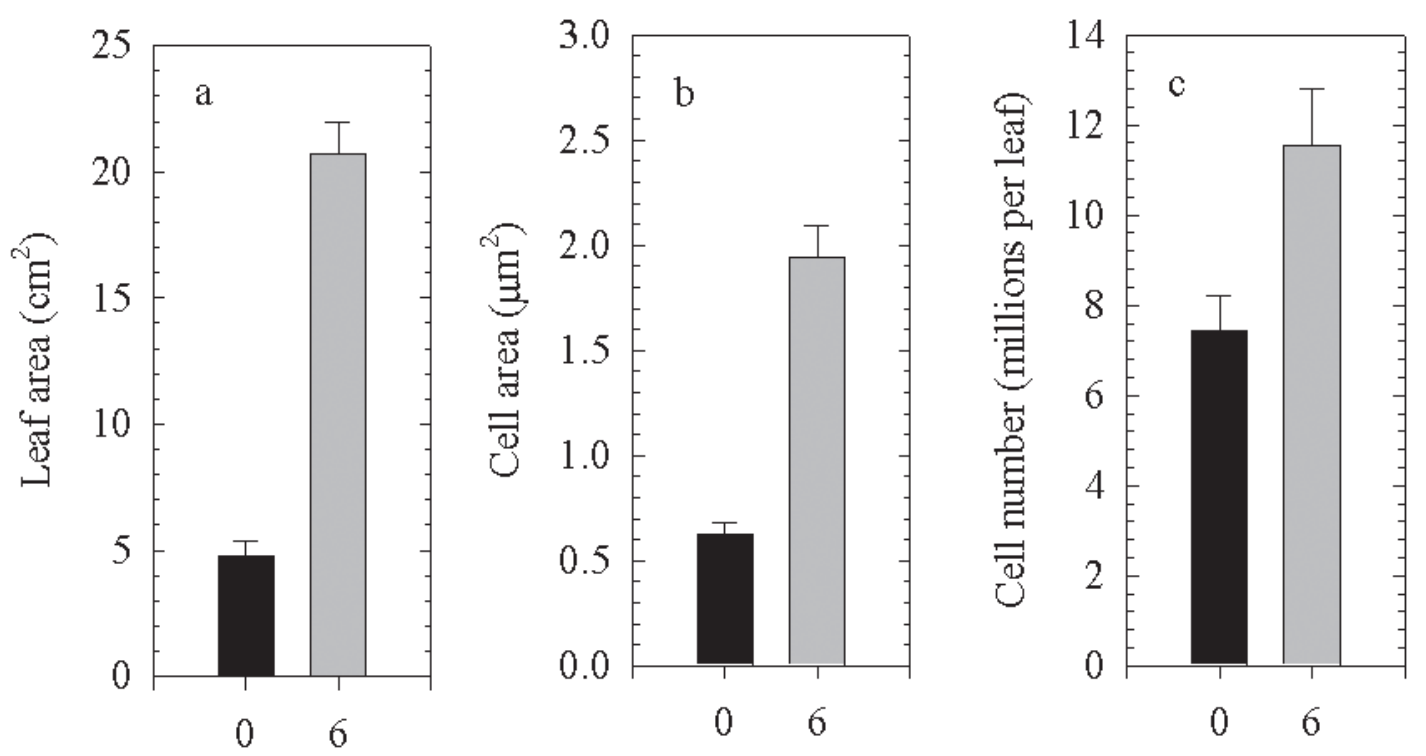

\section{Blue Light Fraction (\%)}

Fig. 6. Effect of $<0.1 \%$ and $6 \%$ blue light on lettuce (a) leaf area, (b) leaf epidermal cell area, and (c) leaf epidermal cell number. Error bars represent the standard error of the means. Blue light fraction is the percentage of blue light (320 to $496 \mathrm{~nm})$ to total (320 to $700 \mathrm{~nm}$ ).

Table 1. Blue light fractions and subsequent red : far-red ratios and phytochrome photoequilibriums ${ }^{\mathrm{z}}$ used in blue light growth and histology studies. Two lamp types were used, high-pressure sodium (HPS) and metal halide (MH). Values for sunlight are shown for comparison.

\begin{tabular}{|c|c|c|c|c|}
\hline $\begin{array}{l}\text { Lamp } \\
\text { type }\end{array}$ & $\begin{array}{l}\text { Blue light fractiony } \\
\text { (\% of } 320-700 \mathrm{~nm})\end{array}$ & $\begin{array}{l}\text { Red to } \\
\text { far-red } \\
\text { ratio }^{x}\end{array}$ & $\begin{array}{c}\text { Phytochrome } \\
\text { photoequilibrium } \\
\left(\mathrm{P}_{\mathrm{fr}} / \mathrm{P}_{\text {total }}\right)\end{array}$ & $\begin{array}{c}\text { Species } \\
\text { treated and } \\
\text { plant part } \\
\text { sampled }\end{array}$ \\
\hline HPS & 0.1 & 2.80 & 0.86 & $\begin{array}{l}\text { Soybean stem } \\
\text { Lettuce leaf }\end{array}$ \\
\hline HPS & 6 & 2.86 & 0.85 & $\begin{array}{l}\text { Soybean leaf } \\
\text { Lettuce leaf }\end{array}$ \\
\hline MH & 26 & 5.11 & 0.82 & $\begin{array}{l}\text { Soybean stem } \\
\text { Soybean leaf }\end{array}$ \\
\hline Sunlight & $27-33$ & $1.05-1.25$ & $0.70-0.75$ & --- \\
\hline
\end{tabular}

zSager and McFarlane (1997).

yBlue light is considered to be 320 to $496 \mathrm{~nm}$ as discussed in Dougher and Bugbee (2001).

xWhere red is 600 to $700 \mathrm{~nm}$ and far-red is 700 to $800 \mathrm{~nm}$.

long term to $26 \%$ blue compared to $0 \%$ blue (Fig. 2 b).

Microscope photographs did not visually indicate any difference in soybean leaf epidermal cells between blue light treatments (Fig. 3). The 23\% decrease in soybean leaf area (Fig. 4a) caused by increasing blue light fraction from $6 \%$ to $26 \%$ was associated with a $15 \%$ decrease in cell area (Fig. 4b) and an $11 \%$ decrease in cell number (Fig. 4c). However, only the differences in cell area were statistically significant. This suggests that changes in leaf area may be primarily influenced by cell expansion, and cell division has less influence. While Van Volkenburgh et al. (1990) found blue light is as effective as red light at stimulating cell expansion in short-term exposure of $P$. vulgaris leaf discs, increasing blue light from $6 \%$ to $26 \%$ decreased cell expansion of soybean plants in this long-term study.

In microscope photographs, lettuce leaf epidermal cell size visually increased as blue light fraction increased from $0 \%$ to $6 \%$ blue (Fig. 5). Indeed, the 4.4-fold increase in lettuce leaf area between $0 \%$ and $6 \%$ blue (Fig. 6a) was caused by a 3.1-fold increase in cell area and a 1.6-fold increase in cell number (Fig. $6 \mathrm{~b}$ and c). The change in lettuce leaf cell expansion, although opposite that of soybean, also raises the question of the effectiveness of blue light compared to red in stimulating cell expansion. For lettuce leaves, both blue and red light may be necessary to trigger the expansion responses. Because red light was provided in all treatments (Table 1), it appears that blue light may be more effective at eliciting the expansion response in contrast to the results of Van Volkenburg et al. (1990). These discrepancies in cell expansion may be due to the fact that our plants were exposed to treatments at imbibition, whereas Van Volkenburgh et al. (1990) used leaf discs from plants that were grown first under white fluorescent lamps and were only treated under red or blue lights for a short time.

Whether cell division and/or cell expansion was affected by blue light was dependent on both species and plant part. In lettuce, which is highly sensitive to blue light fraction (Dougher and Bugbee, 2001), both cell expansion and cell division were significantly increased with increasing blue light fraction. In contrast, in 
soybean, which is less sensitive to blue light fraction than lettuce (Dougher and Bugbee, 2001), only cell expansion was inhibited as blue light fraction increased.

Exposure to increasing blue light fraction affected different cell processes in different parts of the soybean plant. Although both soybean leaf area and stem length decreased with increasing blue light fraction, the leaf area decrease was primarily driven by a decrease in cell size, whereas stem length was decreased by a reduction in cell division. Cell division and cell enlargement are driven by very different pathways. To study the biochemical pathways affected by altered blue light fraction, species responses to blue light need to be identified and the processes of each plant organ studied separately.

\section{Literature Cited}

Brown, C.S., A.C. Schuerger, and J.C. Sager. 1995. Growth and photomorphogenesis of pepper plants under red light-emitting diodes with supplemental blue or far-red lighting. J. Amer. Soc. Hort. Sci. 120:808-813.

Cosgrove, D. 1981. Rapid suppression of growth by blue light. Plant Physiol. 67:584-590.

Dale, J.E. 1988. The control of leaf expansion. Annu. Rev. Plant Physiol. Mol. Biol. 39:267-295.

Dale, J.E. and F.L. Milthorpe. 1983. General features of the production and growth of leaves, p. 151-269. In: J.E. Dale and F.L. Milthorpe (eds.). The growth and functioning of leaves. Cambridge Univ. Press, Cambridge, Mass.
Dougher, T.A.O. and B. Bugbee. 2001. Differences in the response of wheat, soybean, and lettuce to reduced blue radiation. Photochem. Photobiol. 73(2):199-207.

Goins, G.D., N.C. Yorio, M.M. Sanwo, and C.S. Brown. 1997. Photomorphogenesis, photosynthesis, and seed yield of wheat plant grown under red light-emitting diodes (LEDs) with and without supplemental blue lighting. J. Expt. Bot. 48:1407-1413.

Guerra, D., A.J. Anderson, and F.B. Salisbury. 1985. Reduced phenylalanine ammonia-lyase and tyrosine ammonia-lyase activities and lignin synthesis in wheat grown under low pressure sodium lamps. Plant Physiol. 78:126-130.

Hoenecke, M.E., R.J. Bula, and T.W. Tibbitts. 1992. Importance of 'blue' photon levels for lettuce seedlings grown under red-light-emitting diodes. HortScience 27:427-430.

Kigel, J. and D.J. Cosgrove. 1991. Photoinhibition of stem elongation by blue and red light. Plant Physiol. 95:1049-1056.

Kutschera, U. 1992. The role of the epidermis in the control of elongation growth in stems and coleoptiles. Botanica Acta 105:246-252.

Rahim, M.A. and R. Fordham. 1991. Effect of shade on leaf and cell size and number of epidermal cells in garlic (Allium sativum). Ann. Bot. 67:167-171.

Sager, J.C. and J.C. McFarlane. 1997. Radiation, p. 1-29. In: R.W. Langhans and T.W. Tibbitts (eds.). Plant growth chamber handbook. North Central Reg. Res. Publ. 340.

Shinkle, J.R. and R.L. Jones. 1988. Inhibition of stem elongation in Cucumis seedlings by blue light requires calcium. Plant Physiol. 86:960-966.

Van Volkenburgh, E., R.E. Cleland, and M. Watanabe. 1990. Light-stimulated cell expansion in bean (Phaseolus vulgaris L.) leaves. II. Quantity and quality of light required. Planta 182:77-80. 